\title{
A STUDY OF PROJECT-BASED LEARNING IN AN INTRODUCTORY MIS COURSE
}

\author{
Bryan Marshall, Georgia College, bryan.marshall@gcsu.edu \\ Peter Cardon, University of Southern California, cardon@marshall.usc.edu \\ JoyGodin, Georgia College,joy.godin@gcsu.edu
}

\begin{abstract}
In the past several decades, MIS programs have suffered several periods of lower enrollments. In the most recent downturn of enrollments (following the dotcom bust of the early 2000s), many programs have attempted to reimagine their curricula and marketing to appeal to more students. One way we have attempted to revitalize our program during the past five years is with a project-based introductory MIS course that all business students take. Our primary goals for changing the course were the following: (a) create an introductory MIS course that helped business majors better understand the role of IS in business; (b) create an introductory MIS course that engaged business majors in the IS process; and (c) create an introductory MIS course that attracted non-MIS business students to MIS as a major or minor. To help us understand the students' experiences in this course, we created a survey that addressed the following areas: (a) knowledge of IS topics; (b) enjoyment of IS topics; (c) perceived difficulty of IS topics; (d) perceived importance of IS topics to their careers; and (d) interest in MIS minors and majors. Our study spanned six semesters over four years. Altogether, we surveyed 399 non-MIS business majors during this period. Overall, we came to a number of major conclusions. First, business students are getting an excellent picture of the IS story. Second, web design is the most attractive topic. Finally, the project-based approach to foundational IS topics in an introductory course provides modest benefits in interest in MIS majors and minors.
\end{abstract}

Keywords: project-based learning, experiential learning, enrollment, MIS introductory courses

\section{INTRODUCTION}

In the past several decades, MIS programs have suffered several periods of lower enrollments. In the most recent downturn of enrollments (following the dotcom bust of the early 2000s), many programs have attempted to reimagine their curricula and marketing to appeal to more students. Similarly, our program suffered drops in enrollment in the early 2000s. Over the past ten years, however, we have seen steady rises in enrollments. We've applied a variety of strategies. One of the most important strategies we've applied is to reinvent our introductory MIS course offered to all business students. Starting in 2010, we began surveying non-MIS business majors prior to and after taking the course. In this article, we report the findings of these surveys and explain how our philosophy in this course has helped energize our program and better serve our non-MIS business majors.

\section{LITERATURE REVIEW}

In this literature review, we provide the background for changes we made in our introductory MIS course that is offered to all business students. We begin to document the most recent drop in enrollment in MIS programs. We briefly explain some of the responses to this downturn. Then, we cite just a few of the calls for more project-based learning in MIS programs and courses.

MIS enrollment began the most recent major decline in enrollment around 2001 with a recession in the technology industry. Nearly a decade later, MIS enrollments were still estimated to be down nearly 25 to 50 percent. This decline has created a number of pressures on MIS program administrators and professors, including smaller budgets, hiring freezes, increased scrutiny from college and university administrators, and even the phasing out of programs. These challenges make it difficult to restore MIS programs to their prior strength. One of the major challenges of attracting MIS majors is that there are many myths about MIS, including that many technology positions have been or will be outsourced. Common approaches to attract more MIS majors have included better recruiting methods and redesigned curricula $[3,15]$.

In the past five years, computing majors have risen. However, most of this growth appears to be in computer science programs, with modest or flat growth in MIS programs. In fact, while other computing majors rose significantly in 


\section{Issues in Information Systems}

Volume 15, Issue II, pp. 24-30, 2014

the most recent year of the survey, MIS majors declined. Most observers of MIS enrollment trends suggest that MIS programs need to implement a variety of strategies to get into a stronger growth trend $[4,6,16]$.

Many examples exist of introductory courses being used to attract MIS students [2,4,7,8,9]. Frost and Pike (2004) are the first known MIS scholars to examine project-based introductory MIS courses. They explained that one reason they introduced a project-based approach was the declining enrollments of MIS majors. They argued that their students found a project-based approach much more engaging, energetic, and motivating for MIS and non-MIS majors. While they provide a few anecdotal examples, they did not provide any statistics to explain the impact of these project-based courses [9]. In response to what they refer to as the "enrollment crisis" of declining numbers of MIS majors, Firth and colleagues (2008) proposed that the using the MIS introductory course as a recruiting strategy was essential. They used a variety of studies to show that to attract interest from non-MIS majors, the course should be innovative, interesting, and "tell the IS story" [8].

A variety of research has shown that project-based learning is often superior to lecture-style, abstract learning in MIS courses $[1,7,12,13]$. Yet, many MIS programs have traditionally reserved a heavier emphasis on project-based learning for the end of programs. For example, a common approach to project-based learning has occurred in capstone MIS courses. In fact, a recent survey of MIS instructors showed that 69 percent of their programs used a live project for the capstone MIS course [11]. Based on our review of innovations in other programs, our goal was to flip this approach by providing project-based learning in the introductory course to-in the words of Firth and colleges- "tell the IS story" [8].

\section{RESEARCH METHODOLOGY}

Just over five years ago, we significantly altered our introductory course. Beginning in 2010, we began surveying non-MIS majors before and after the course to help us understand their experiences. Our primary goals for changing the course were the following: (a) create an introductory MIS course that helped business majors better understand the role of IS in business; (b) create an introductory MIS course that engaged business majors in the IS process; and (c) create an introductory MIS course that attracted non-MIS business students to MIS as a major or minor.

Our university is a small, public liberal arts college capped at 6,000 students. The college of business is AACSB accredited and has been since the 1997. The information systems department offers both a Bachelor of Business Administration degree with an emphasis in Information Systems and a Bachelor of Science degree in computer science. Over the past ten years, we have implemented a variety of strategies to increase enrollment of MIS majors. We have been fairly successful with over twice as many majors as ten years ago (see Figure 1). Creating a stronger introductory MIS course has been part of the formula for success.

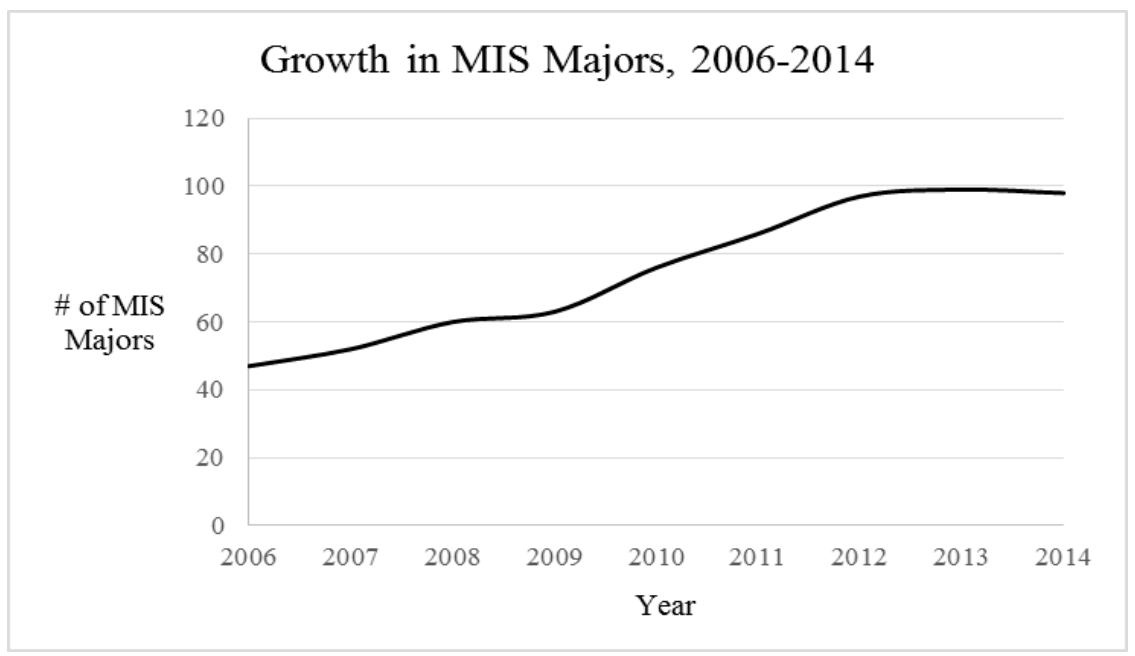

Figure 1. Growth of the MIS Program at a Small Liberal Arts University. 


\section{Issues in Information Systems}

Volume 15, Issue II, pp. 24-30, 2014

When we first started thinking about changing the content of the introductory MIS course (called "Introduction to Computers"), our primary concern was the content. We were teaching some theory of computing like hardware and software, but the main focus was teaching Microsoft Word, Excel, and PowerPoint. We felt this was not giving business students a valuable perspective of IS in the workplace, so we shifted that content down to a 1000 level computing course and let student's test out of it if they had the appropriate skills. This allowed us to really focus on higher IS skills. Due to our decreasing enrollments, we hoped this new course would help reverse the trend. Fulltime tenure track professors taught this course with a track record for good teaching.

To tell the IS story, we focused on four areas because they were the foundation of information systems: web design, databases, programming, and networking. These four topics were a natural fit for our program. Our majors get depth with many courses in each area. Our minors take at least one course in each of these topics. As we developed the new introductory course, we were hoping to get the students immersed in actual MIS type projects: building websites, putting networks together, designing and implementing databases, and solving problems by writing applications using Visual Basic. We were hoping that if students could see what MIS was actually about, instead of just learning abstract and theoretical principles, they would be more engaged and this would spark their interest in computing. Each project was a major portion of the course. We still had lectures on theory and used the projects to give the students some real world hands on experience. For example, when the students were starting the programing project, we lectured on programming and designing applications. We then applied the principles in the project.

To help us understand the students' experiences in this course, we created a survey that addressed the following areas: (a) knowledge of IS topics; (b) enjoyment of IS topics; (c) perceived difficulty of IS topics; (d) perceived importance of IS topics to their careers; and (e) interest in MIS minors and majors. Our study spanned six semesters over four years. Altogether, we surveyed 399 non-MIS business majors during this period: Fall 2010, 65 students; Spring 2011, 42 students; Fall 2011, 114 students; Spring 2012, 93 students; Fall 2012, 68 students; and Spring 2013, 17 students. Roughly 59 percent $(n=237)$ of the students were men and 41 percent $(n=162)$ were women. Altogether, 366 of these students took a pre-test and 156 took a post-test.

We primarily analyzed our data with descriptive statistics. One of our major goals was to see how much students perceived growth in knowledge in each area. As a result, we used Cohen's $d$ to identify effect size for our survey questions about knowledge of IS topics. Generally, an effect size of .2 is considered small; an effect size of .5 is considered medium; and an effect size of .85 is considered large (although many studies show that the effect size should be labeled cautiously) $[5,14]$.

\section{RESULTS}

Of students who took the pre-class survey, just 64 percent (234) had heard of MIS. Overall, non-MIS majors reported significant progress, largely because they enter the course with none or basic knowledge of each of the IS areas (see Table 1 for responses before and after the course about their knowledge of IS areas). Students tend to report knowing the most about networking before the class, albeit very few (13.3\%) report more than a basic understanding. They report knowing the least programming, with just 2.7 percent of students reporting than a basic understanding.

In Table 2, we report the effect sizes for increase in knowledge in these four IS areas. In each case, the impact is large. The areas where students report the largest increase in knowledge are in web design and databases. Roughly $66 \%$ of students report intermediate or advanced knowledge of web design, and about $60 \%$ report intermediate or advanced knowledge of databases. 
Table 1. Knowledge of IS Concepts Before and After the Class.

\begin{tabular}{l|cccc|cccc}
\hline & \multicolumn{4}{|c|}{ Before Class } & \multicolumn{4}{c}{ After Class } \\
& $\begin{array}{c}\text { None } \\
(\mathbf{1})\end{array}$ & $\begin{array}{c}\text { Basic } \\
(\mathbf{2})\end{array}$ & $\begin{array}{c}\text { Intermediate } \\
(\mathbf{3})\end{array}$ & $\begin{array}{c}\text { Advanced } \\
(\mathbf{4})\end{array}$ & $\begin{array}{c}\text { None } \\
(\mathbf{1})\end{array}$ & $\begin{array}{c}\text { Basic } \\
(\mathbf{2})\end{array}$ & $\begin{array}{c}\text { Intermediate } \\
(\mathbf{3})\end{array}$ & $\begin{array}{c}\text { Advanced } \\
(\mathbf{4})\end{array}$ \\
\hline \multirow{2}{*}{ Web Design } & $52.5 \%$ & $40.4 \%$ & $6.8 \%$ & $.3 \%$ & $5.8 \%$ & $28.2 \%$ & $55.1 \%$ & $10.9 \%$ \\
& $(192)$ & $(148)$ & $(25)$ & $(1)$ & $(9)$ & $(44)$ & $(86)$ & $(17)$ \\
\hline \multirow{2}{*}{ Programming } & $70.8 \%$ & $26.5 \%$ & $2.7 \%$ & $0 \%$ & $12.8 \%$ & $50.6 \%$ & $31.4 \%$ & $5.1 \%$ \\
& $(259)$ & $(97)$ & $(10)$ & $(0)$ & $(20)$ & $(79)$ & $(49)$ & $(8)$ \\
\hline \multirow{2}{*}{ Database } & $56.8 \%$ & $36.9 \%$ & $6.0 \%$ & $.3 \%$ & $8.3 \%$ & $31.4 \%$ & $52.6 \%$ & $7.7 \%$ \\
& $(208)$ & $(135)$ & $(22)$ & $(1)$ & $(13)$ & $(49)$ & $(82)$ & $(12)$ \\
\hline \multirow{2}{*}{ Networking } & $41.0 \%$ & $45.6 \%$ & $11.7 \%$ & $1.6 \%$ & $7.1 \%$ & $41.7 \%$ & $45.5 \%$ & $5.8 \%$ \\
& $(150)$ & $(167)$ & $(43)$ & $(6)$ & $(11)$ & $(65)$ & $(71)$ & $(9)$ \\
\hline
\end{tabular}

Note. In response to the question How much do you know about the following areas? (web design, programming, database, networking).

Table 2. Effect Sizes for Knowledge of IS Concepts Before and After the Class.

\begin{tabular}{lcccccc}
\hline & \multicolumn{2}{c}{ Before Class } & \multicolumn{2}{c}{ After Class } & \multicolumn{1}{c}{} \\
& $\boldsymbol{M}$ & $\boldsymbol{S D}$ & $\boldsymbol{M}$ & $\boldsymbol{S D}$ & $\boldsymbol{d}$ & $\boldsymbol{p}$ \\
\hline Web Design & 1.55 & 0.63 & 2.71 & 0.74 & 1.69 & $.00^{* *}$ \\
Programming & 1.32 & 0.52 & 2.29 & 0.75 & 1.41 & $.00^{* *}$ \\
Database & 1.50 & 0.62 & 2.60 & 0.75 & 1.60 & $.00^{* *}$ \\
Networking & 1.74 & 0.73 & 2.50 & 0.71 & 1.06 & $.00^{* *}$ \\
\hline
\end{tabular}

Note. In response to the question How much do you know about the following areas? (web design, programming, database, networking). Scale from 1 (none) to 4 (advanced). ${ }^{* *} p<.01$.

As far as anticipated and actual enjoyment of these IS areas, web design was clearly the favorite (see Table 3 for a summary of responses about enjoyment of IS topics). Roughly $66 \%$ of students expected it to be the most enjoyable before the semester, and about $79 \%$ ended out saying it was their favorite topic. Databases was expected to be the least favorite topic with just $4 \%$ of students expecting it to be their top choice. After the course, students seemed to rank it slightly more positively, however. Similarly, programming was expected to not be relatively enjoyable but ended out with more positive views than the other areas. The one IS area that ended out with relatively lower enjoyment was networking. Roughly $65 \%$ of students started the course expected it to be their first or second most enjoyable topic. However, just $41 \%$ of students ended out ranking it as their first or second most enjoyable IS topic after the course.

Table 3. Enjoyment of IS Topics.

\begin{tabular}{|c|c|c|c|c|c|c|c|c|}
\hline & \multicolumn{4}{|c|}{ Expectations About Enjoyment Before Class } & \multicolumn{4}{|c|}{ Reactions About Enjoyment After Class } \\
\hline & $\begin{array}{c}1^{\text {st }} \\
\text { Choice }\end{array}$ & $\begin{array}{c}2^{\text {nd }} \\
\text { Choice }\end{array}$ & $\begin{array}{c}3^{\text {rd }} \\
\text { Choice }\end{array}$ & $\begin{array}{c}4^{\text {th }} \\
\text { Choice }\end{array}$ & $\begin{array}{c}1^{\text {st }} \\
\text { Choice }\end{array}$ & $\begin{array}{c}2^{\text {nd }} \\
\text { Choice }\end{array}$ & $\begin{array}{c}3^{\text {rd }} \\
\text { Choice }\end{array}$ & $\begin{array}{c}4^{\text {th }} \\
\text { Choice }\end{array}$ \\
\hline Web Design & $\begin{array}{c}65.6 \% \\
(240)\end{array}$ & $\begin{array}{c}22.1 \% \\
(81)\end{array}$ & $\begin{array}{l}7.7 \% \\
(28)\end{array}$ & $\begin{array}{c}4.6 \% \\
(17)\end{array}$ & $\begin{array}{l}78.8 \% \\
(123)\end{array}$ & $\begin{array}{c}13.5 \% \\
(21)\end{array}$ & $\begin{array}{c}6.4 \% \\
(10)\end{array}$ & $\begin{array}{c}1.3 \% \\
(2)\end{array}$ \\
\hline Programming & $\begin{array}{l}6.6 \% \\
(24)\end{array}$ & $\begin{array}{c}19.7 \% \\
(72)\end{array}$ & $\begin{array}{c}35.2 \% \\
(129)\end{array}$ & $\begin{array}{c}38.5 \% \\
(141)\end{array}$ & $\begin{array}{c}12.8 \% \\
(20)\end{array}$ & $\begin{array}{c}23.7 \% \\
(37) \\
\end{array}$ & $\begin{array}{c}26.3 \% \\
(41)\end{array}$ & $\begin{array}{c}36.5 \% \\
(57)\end{array}$ \\
\hline Database & $\begin{array}{c}3.6 \% \\
(13)\end{array}$ & $\begin{array}{c}17.5 \% \\
(64) \\
\end{array}$ & $\begin{array}{c}33.6 \% \\
(123)\end{array}$ & $\begin{array}{c}45.4 \% \\
(166) \\
\end{array}$ & $\begin{array}{c}5.8 \% \\
(9) \\
\end{array}$ & $\begin{array}{c}24.4 \% \\
(38) \\
\end{array}$ & $\begin{array}{c}39.7 \% \\
(62) \\
\end{array}$ & $\begin{array}{c}30.1 \% \\
(47)\end{array}$ \\
\hline Networking & $\begin{array}{c}24.3 \% \\
(89)\end{array}$ & $\begin{array}{c}40.7 \% \\
(149)\end{array}$ & $\begin{array}{c}23.8 \% \\
(87)\end{array}$ & $\begin{array}{c}11.2 \% \\
(41)\end{array}$ & $\begin{array}{c}2.6 \% \\
(4)\end{array}$ & $\begin{array}{c}38.5 \% \\
(60)\end{array}$ & $\begin{array}{c}27.6 \% \\
(43)\end{array}$ & $\begin{array}{c}31.4 \% \\
(49)\end{array}$ \\
\hline
\end{tabular}

Note. In response to the question Which of these do you think you will enjoy the most? Rank the four projects in the order that you think you will like. Students rank-ordered these topics from 1 to 4. 


\section{Issues in Information Systems}

Volume 15, Issue II, pp. 24-30, 2014

Non-MIS students overwhelmingly thought programming and databases would be the most difficult IS topics (see Table 4 for a summary of responses about difficulty of IS topics). After taking the course, they still felt the same way. Similarly, students expected web design and networking to be comparatively easier and those expectations matched their experiences in the class.

Table 4. Difficulty of IS Topics.

\begin{tabular}{|c|c|c|c|c|c|c|c|c|}
\hline & \multicolumn{4}{|c|}{ Expectations About Difficulty Before Class } & \multicolumn{4}{|c|}{$\underline{\text { Reactions About Difficulty After Class }}$} \\
\hline & Most & $\begin{array}{c}\text { 2nd } \\
\text { Most }\end{array}$ & $\begin{array}{c}\text { 3rd } \\
\text { Most }\end{array}$ & Least & Most & $\begin{array}{c}\text { 2nd } \\
\text { Most }\end{array}$ & $\begin{array}{c}\text { 3rd } \\
\text { Most }\end{array}$ & Least \\
\hline Web Design & $\begin{array}{c}8.7 \% \\
(32)\end{array}$ & $\begin{array}{c}19.9 \% \\
(73)\end{array}$ & $\begin{array}{c}24.3 \% \\
(89)\end{array}$ & $\begin{array}{c}47.0 \% \\
(172)\end{array}$ & $\begin{array}{c}6.4 \% \\
(10)\end{array}$ & $\begin{array}{c}3.2 \% \\
(5)\end{array}$ & $\begin{array}{c}17.9 \% \\
(28)\end{array}$ & $\begin{array}{c}72.4 \% \\
(113) \\
\end{array}$ \\
\hline Programming & $\begin{array}{c}60.4 \% \\
(221)\end{array}$ & $\begin{array}{c}21.0 \% \\
(77)\end{array}$ & $\begin{array}{c}12.6 \% \\
(46)\end{array}$ & $\begin{array}{c}6.0 \% \\
(22)\end{array}$ & $\begin{array}{c}53.2 \% \\
(83)\end{array}$ & $\begin{array}{c}21.8 \% \\
(34)\end{array}$ & $\begin{array}{c}15.4 \% \\
(24)\end{array}$ & $\begin{array}{c}9.6 \% \\
(15)\end{array}$ \\
\hline Database & $\begin{array}{c}22.7 \% \\
(83)\end{array}$ & $\begin{array}{c}39.1 \% \\
(143)\end{array}$ & $\begin{array}{c}28.4 \% \\
(104)\end{array}$ & $\begin{array}{c}9.8 \% \\
(36) \\
\end{array}$ & $\begin{array}{c}22.4 \% \\
(35)\end{array}$ & $\begin{array}{c}45.5 \% \\
(71)\end{array}$ & $\begin{array}{c}26.9 \% \\
(42) \\
\end{array}$ & $\begin{array}{c}5.1 \% \\
(8) \\
\end{array}$ \\
\hline Networking & $\begin{array}{c}9.0 \% \\
(33)\end{array}$ & $\begin{array}{c}19.7 \% \\
(72)\end{array}$ & $\begin{array}{c}34.4 \% \\
(126)\end{array}$ & $\begin{array}{c}36.9 \% \\
(135)\end{array}$ & $\begin{array}{c}17.3 \% \\
(27)\end{array}$ & $\begin{array}{c}29.5 \% \\
(46)\end{array}$ & $\begin{array}{c}38.5 \% \\
(60)\end{array}$ & $\begin{array}{c}14.7 \% \\
(23)\end{array}$ \\
\hline
\end{tabular}

Note. In response to the question Which of the following topics do you think will be the most difficult? Rank the four projects in terms of difficulty. Students rank-ordered these topics from 1 to 4.

Perhaps no area of expectations more mismatched actual experiences than perceived importance to career (see Table 5 for a summary of responses about perceived importance to career of IS topics). Nearly half (45.1\%) of students entered the class anticipated that networking would be most important to their careers. By the end of the class, just one in five (21.8\%) felt networking would be most important to their career. About one quarter $(24.3 \%)$ of students entered the course expected web design to be the most important to their careers. By the end of the course, about one half (46.8\%) thought web design would be most important to their careers. Behind web design, databases ended out being considered the most important IS topic for their careers among about one quarter $(26.3 \%)$ of students. Programming was considered the least important before and after the course.

Table 5. Importance to Career of IS Topics.

\begin{tabular}{l|cccc|cccc}
\hline \multirow{2}{*}{} & \multicolumn{4}{|c|}{ Expectations About Career Importance } & \multicolumn{4}{c}{ Reactions About Career Importance } \\
& \multicolumn{4}{c}{ Before Class } & \multicolumn{4}{c}{ After Class } \\
& Most & 2nd Most & 3rd Most & Least & Most & 2nd Most & 3rd Most & Least \\
\hline \multirow{2}{*}{ Web Design } & $24.3 \%$ & $24.3 \%$ & $20.5 \%$ & $30.9 \%$ & $46.8 \%$ & $21.8 \%$ & $20.5 \%$ & $10.9 \%$ \\
& $(89)$ & $(89)$ & $(75)$ & $(113)$ & $(73)$ & $(34)$ & $(32)$ & $(17)$ \\
\hline \multirow{2}{*}{ Programming } & $8.5 \%$ & $13.1 \%$ & $32.5 \%$ & $45.9 \%$ & $5.1 \%$ & $14.1 \%$ & $23.7 \%$ & $57.1 \%$ \\
& $(31)$ & $(48)$ & $(119)$ & $(168)$ & $(8)$ & $(22)$ & $(37)$ & $(89)$ \\
\hline \multirow{2}{*}{ Database } & $22.4 \%$ & $32.8 \%$ & $29.2 \%$ & $15.6 \%$ & $26.3 \%$ & $31.4 \%$ & $26.9 \%$ & $15.4 \%$ \\
& $(82)$ & $(120)$ & $(107)$ & $(57)$ & $(41)$ & $(49)$ & $(42)$ & $(24)$ \\
\hline \multirow{2}{*}{ Networking } & $45.1 \%$ & $29.8 \%$ & $17.5 \%$ & $7.7 \%$ & $21.8 \%$ & $32.7 \%$ & $28.8 \%$ & $16.7 \%$ \\
& $(165)$ & $(109)$ & $(64)$ & $(28)$ & $(34)$ & $(51)$ & $(45)$ & $(26)$ \\
\hline
\end{tabular}

Note. In response to the question Which of the four areas do you think will be the most important to your business career? Rank the projects in terms of important to your career. Students rank-ordered these topics from 1 to 4.

One purpose of our study was to examine how much the course contributed to interest in MIS programs (see Table 6 for a summary of responses about interest in MIS as a major or minor). Generally, there was modest growth in interest in minors and majors. Prior to taking the course, roughly $37 \%$ of students expressed some or strong interest in a MIS minor. After taking the course, about $45 \%$ of students expressed some or strong interest in an MIS minor. Prior to taking the course, roughly $13 \%$ of students expressed interest in MIS as a major. After taking the course, about $18 \%$ of students expressed some or strong interest in an MIS major. 
Table 6. Interest in MIS as a Major or Minor.

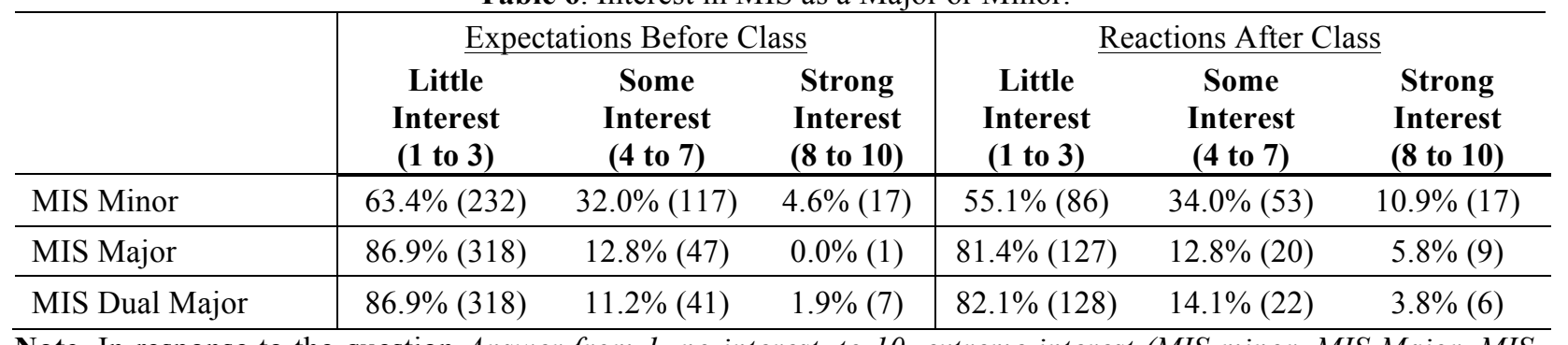

Note. In response to the question Answer from 1, no interest, to 10, extreme interest (MIS minor, MIS Major, MIS Dual Major).

\section{CONCLUSIONS}

Overall, we came to a number of major conclusions. First, based on the results of this survey, business students have a greater awareness of the IS program. They are grappling with real-life IS problems that business face in a handson environment. Our survey shows that they enter the course knowing next to nothing and leave the course with the perception that they know much more. In particular, they believe they grow the most in the areas of web design and databases.

Second, web design is the most attractive topic. Students entered the course are most interested in the topic, and they leave the course with even more interest than they started. Furthermore, they enter the course thinking it is the least difficult topic, and they leave the course with this view even more strongly developed. Perhaps most importantly, after having been exposed to each of the four IS topics, they leave the course believing it is most important to their careers. This surveys reveals that web design should be an important part of our marketing and promotion efforts. While we certainly don't think we should gloss over the other topics, web design clearly has attractiveness as far as interest, ease, and value.

Finally, the project-based approach to foundational IS topics in an introductory course provides modest benefits in interest in MIS majors and minors. The survey results show a roughly 5 to 10 percent increase in interest MIS majors and minors. While we can't control perfectly for the doubling of our enrollments over the past decade, we believe our project-based approach—starting right from the introductory course-is an important part of this growth.

\section{REFERENCES}

1. Ali, A., DeLorenzo, G. J., Mensch, S., \& Kohun, F. G. (2008). Integrating service-learning projects into technology courses: The experience of two programs. Issues in Information Systems, 9(1), 121-128.

2. Barnes, C., \& Bandyopadhyay, K. (2012). A successful curriculum strategy to increase MIS enrollment. Proceedings of the Southwestern DSI.

3. Becker, J., Hassan, N., \& Naumann, J. D. (2006). Combating the enrollment downtown in IS/IT programs. Proceedings of the Twelfth Americas Conference on Information Systems, 2289-2298.

4. Buche, M. W. (2010). MIS vision 2015. Self-published manuscript.

5. Cohen, J. (1988). Statistical power analysis for the behavioral sciences $\left(2^{\text {nd }}\right.$ ed.). Hillsdale, NJ: Lawrence Earlbaum Associates.

6. Downey, J. P., McGaughey, R., \& David, Roach. (2009). MIS versus computer science: An empirical comparison of the influences on the students' choice of major. Journal of Information Systems Education, 20(3), 357-368.

7. Duvall, S., \& Kleckner, M. (2008). Lessons learned: The creation of a CS/CIS gateway class. Issues in Information Systems, 9(1), 101-104.

8. Firth, D., Lawrence, C., \& Looney, C. A. (2008). Addressing the IS enrollment crisis: A 12-step program to bring about change through the introductory IS course. Communications of the Association for Information Systems, 23, 17-36.

9. Frost, R. D., \& Pike, J. C. (2004). A revolutionary approach to introductory MIS: Professional, project based, decision focused, visual and engaging. Issues in Information Systems, 5(2), 454-460. 


\section{Issues in Information Systems}

Volume 15, Issue II, pp. 24-30, 2014

10. Fulton, J. P., \& Strickland, T. J., Jr. (2009). A Web development framework for team-based project courses. Issues in Information Systems, 10(1), 237-245.

11. Kovalchick, L. L., Boff, G. M., \& Kovacs, P. J. (2013). Using live projects in an information systems capstone course. Issues in Information Systems, 14(2), 149-155.

12. Mykytyn, K., Pearson, A., Paul, S., \& Mykytyn, P. P., Jr. (2008). The use of problem-based learning to enhance MIS eduction. Decision Sciences Journal of Innovative Education, 6(1), 89-113.

13. Ngai, E. W. T. (2007). Learning in introductory e-commerce: A project-based teamwork approach. Computers \& Education, 48(1), 17-29.

14. Rosenthal, R., \& Rosnow, R. L. (1991). Essential of behavioral research: Methods and data analysis ( ${ }^{\text {nd }}$ ed.). New York: McGraw-Hill.

15. Saunders, G., \& Lockridge, T. M. (2011). Declining MIS enrollment: The death of the MIS degree? Contemporary Issues in Education Research, 4(1), 15-26.

16. Zweben, S. (2013). Computing degree and enrollment trends: From the 2011-2012 CRA Taulbee survey. Washington, DC: Computer Research Association. 